\title{
Direct costs of rescue procedures to manage vascular access complications in conventional hemodialysis*
}

\author{
Custos diretos dos procedimentos de resgate para manejo das complicações do \\ acesso vascular para hemodiálise convencional \\ Costos directos de los procedimientos de rescate para manejo de las complicaciones del \\ acceso vascular para hemodiálisis convencional
}

How to cite this article:

Melo ACT, Lima AFC. Direct costs of rescue procedures to manage vascular access complications in conventional hemodialysis. Rev Esc Enferm USP. 2021;55:e20210156. DOI: https://doi.org/10.1590/1980-220X-REEUSP-2021-0156.

\section{Ana Cláudia Tavares de Melo ${ }^{1}$ \\ iD Antônio Fernandes Costa Lima²}

* Extracted from the thesis "Custos associados ao manejo das complicações de acesso vascular para hemodiálise", Universidade de São

Paulo, Escola de Enfermagem, 2020.

${ }^{1}$ Universidade de São Paulo, Hospital Universitário, Departamento de Enfermagem, São Paulo,

SP, Brazil.

${ }^{2}$ Universidade de São Paulo, Escola de

Enfermagem, Departamento de Orientação

Profissional, São Paulo, SP, Brazil.
Corresponding author:

Ana Cláudia Tavares de Melo

Av. Professor Lineu Prestes, $n^{\circ} 2565$, Butantã

05508-000 - São Paulo, SP, Brazil

anactm@yahooo.com.br

\section{ABSTRACT}

Objective: To measure the average direct cost of procedures performed by health professionals, in a Dialysis Center, for the management of complications of vascular access for hemodialysis. Method: Quantitative, exploratory-descriptive case study type research. The average direct cost was calculated by multiplying the time spent by health professionals by the unit cost of direct labor, adding this to the input costs (materials/ medicines/solutions). Results: The following average direct costs were obtained: US $\$ 0.72$, US $\$ 2.00$ and US $\$ 1.41$ for "administration of easy-to-dilute, difficult-todilute, and undiluted antibiotics", respectively; \$2.61 for "central venous catheter dressing with topical antibiotic"; $\$ 48.05$ for "alteplase infusion"; US\$183.68 for "insertion of central venous catheter for hemodialysis"; and $\$ 1.31$ for "arteriovenous fistula puncture". Conclusion: Material and drug costs significantly contributed to the composition of the average total direct cost of most procedures.

\section{DESCRIPTORS}

Renal Insufficiency, Chronic; Hemodialysis Units, Hospital; Nephrology Nursing; Catheterization, Central Venous; Arteriovenous Fistula, Costs and Cost Analysis. 


\section{INTRODUCTION}

Chronic Kidney Disease (CKD) is a worldwide public health problem that results in productivity loss and increased costs associated with health care, generating a global economic burden, with a significant socioeconomic impact ${ }^{(1-3)}$.

The number of patients with End-Stage Renal Disease (ESRD), who usually need Renal Replacement Therapy (RRT), through dialysis or kidney transplantation, is growing and constitutes an important problem because it is a high-cost therapeutic modality ${ }^{(4-5)}$. Among the modalities of RRT, Hemodialysis (HD) has been the most used over the years ${ }^{(6)}$; it should be noted that vascular access is essential for the success and efficiency of $\mathrm{HD}^{(7)}$.

Since it is indispensable for HD, vascular access is considered crucial for maintaining life of CKD patients undergoing dialysis ${ }^{(8)}$, and it is obtained, in clinical practice, through the construction of an autologous Arteriovenous Fistula (AVF), prosthetic arteriovenous graft, or insertion of a central venous catheter $(\mathrm{CVC})^{(9)}$.

The maintenance of vascular access has become a critical issue for HD services/dialysis centers (DC) since treatment with dialysis provided an increase in life expectancy of its users, resulting in the performance of long-term HD and requiring access for long-term use ${ }^{(9)}$. Thus, care of vascular access is directly related to the quality of care provided to patients with $\mathrm{CKD}^{(10)}$.

However, as complications related to vascular access are not uncommon, rescue procedures, aiming to improve longevity, have become an important care practice ${ }^{(11)}$. Procedures both for creating and maintaining vascular access, aiming at the efficiency of HD and improvement in the quality of life of patients with $\mathrm{CKD}$, impact the costs attributed to $\mathrm{CKD}$, significantly contributing to the financial burden of this modality of $\mathrm{RRT}^{(12)}$.

Therefore, knowing the costs associated with the performance of rescue procedures for vascular accesses for $\mathrm{HD}$, in care practice, can contribute to improve the management of care provided and the efficient use of the resources involved, in an effort to achieve continuous improvement in clinical and financial results, even supporting assessments of economic sustainability without affecting quality of care.

In this regard, the present study was carried out aiming to measure the average direct cost (ADC) of the procedures performed by health professionals, in a Dialysis Center of a Public Teaching and Research Hospital (HPEP), for the management of vascular access complications for conventional hemodialysis (HD).

\section{METHOD}

\section{Type Of Study}

This is a quantitative, exploratory-descriptive, single case study. Case studies seek to understand a real-life phenomenon, considering its context and investigating it empirically according to a set of procedures, in which data collection and analysis follow the planning rationale, adopting multiple sources of evidence ${ }^{(13)}$.

\section{LOCAL}

The study was conducted on the DC of an HPEP that is a special-purpose instrumentality, associated with a Public University maintained by the State of São Paulo. The DC has 24 machines and serves 118 patients distributed in three shifts from Monday to Saturday. The staff is constituted of the nursing team, which consists of a coordinating nurse, seven clinical nurses, and 26 nursing technicians/assistants (NT/NA), a medical team, with seven nephrologists, two preceptors and five nephrology residents, a nutritionist, a psychologist, and a social worker.

\section{Sample Definition}

The research comprised two stages, the first being retrospective, and the second, prospective.

In the first stage (retrospective), the medical records of 118 patients treated at the DC from July/2018 to July/2019 were included, to provide the analysis of the rescue procedures performed by health professionals for the management of vascular access for conventional HD. It was found that the following procedures performed were documented: "inversion of HD lines"; "administration of antibiotics"; "alteplase infusion for CVC unblocking"; "insertion of long-term HD $\mathrm{CVC}$ " and "AVF puncture".

In the second stage of the study (prospective), the procedure "inversion of the HD lines" was excluded because its performance occurs during the installation of the HD; therefore, it does not consume specific inputs (human and material resources) that would require the determination of its costs. The procedure "administration of antibiotics", intravenously or topically at the insertion site of the CVC, was divided into two distinct procedures: "administration of intravenous antibiotics" and "topical antibiotic dressing at the insertion site of the CVC". Based on the clinical experience of the DC nursing professionals and considering the characteristics related to the dilution of different drugs, the procedure "administration of intravenous antibiotics" was divided into "administration of difficult-to-dilute antibiotics", "administration of easy-to-dilute antibiotics" and "administration of undiluted antibiotics".

Therefore, after this stratification, seven procedures were established: "administration of easy-to-dilute antibiotics"; "administration of difficult-to-dilute antibiotics"; "administration of undiluted antibiotics"; "topical antibiotic dressing at the CVC insertion site"; "alteplase infusion for CVC unblocking"; "insertion of long-term CVC for HD" and "AVF puncture".

Thus, the casuistry of the second stage (prospective) corresponded to the non-participating direct observation opportunities of the seven rescue procedures mentioned above to determine the respective average direct costs (ADCs). Based on the finding, made after technical visits to the DC, that there was no variation in the number of human resources involved and a small variation in the amount of consumed inputs (materials and solutions/medicines) for the feasibility of the seven stratified procedures, a statistician 
established that a minimum of ten observations of each one of them would be enough for the calculation of the ADC.

Thus, the sample, to support the costing, corresponded to 336 direct non-participating observations, in the morning and afternoon, during the performance of the seven rescue procedures by the DC resident physicians and preceptors, nurses, and nursing technicians/assistants.

\section{Data Collection}

Data collection was carried out by the researchers themselves. Initially, data were collected on the rescue procedures of vascular access for HD from the medical records of 118 patients seen at the DC during the study period. This activity, which required an investment of time for a careful analysis of the paper medical records (such as disease course recording and medical and nursing prescriptions, nursing notes), was necessary to support the detailing of documented materials, solutions/medicines for the rescue procedures; subsequent comparison with the current standardization in the DC and validation of the health professionals performing the procedure. Data collection instruments were then developed, also validated by these professionals, to record the consumption of inputs used, number and category of health professionals involved, and time spent (timed) in performing the seven procedures mentioned above to justify their costing.

The second stage of the study was based on the absorption microcosting method, which is highly used in health organizations as it is the only one accepted by the Brazilian legislation in the calculation of Income Tax. In this method, the aim is to identify the cost centers, and all production costs (direct, indirect, fixed and variable) are allocated to the costs of the organization's products and services ${ }^{(14)}$.

However, it is difficult to obtain information in most health organizations for the calculation of indirect costs, making it impossible to calculate the total cost of procedures or processes. Therefore, direct and variable costing, in which inputs are measured (materials, medicines/solutions and direct labor - DL), has been frequently used.

Based on this perspective, the measurement of direct costs was chosen, defined as a monetary expenditure applied in the production of a product or service, capable of being clearly quantified and identified with the product or department ${ }^{(14)}$. In hospital organizations, direct costs are usually made up of equipment and supplies and the DL used in the care process ${ }^{(15)}$. DL refers to personnel who works directly to obtain a product or service provided, as long as the time spent and who performed the work can be identified. It consists of salaries, social charges, provisions for vacations, and year-end mandatory bonus ${ }^{(14)}$.

The calculation of the DL of health professionals performing the seven rescue procedures was made based on the average wages of the payroll (base salary, benefits, bonuses, and social contributions) of nurses and NT/NA, preceptorship grant, and food voucher of the Nephrology preceptor physician and Nephrology resident physician residency grant, all values provided by the HPEP's Human Resources Department, the field of study.
To calculate the costs of materials, medicines/solutions, those in charge of the Purchasing/Warehouse Department were asked to supply the costs of the latest purchases.

Total ADC of a given procedure is obtained from the definition of the average amount of materials $\left[\overline{q m}{ }_{k}\right]$; the average unit price of each material $\left[\overline{P m u_{k}}\right]$; the average amount of solutions/medicines $\left[\overline{q s_{k}}\right]$; the average unit price of each solution/drug $\left[\overline{P s u_{k}}\right]$; the average time of dedication of each professional category $[\bar{t}]$ and the DL average unit payroll of each professional category $[\overline{S u}]$. Therefore, the ADC of each of the seven procedures under study was calculated using the equation $\overline{C\left(P_{1}\right)}=\sum_{k=1}^{n}\left(\overline{q_{k}} \cdot \overline{P u_{k}}\right)+\sum_{k=1}^{n}\left(\overline{q s} \overline{P s}_{k}\right) \sum_{c=1}^{n}\left(\overline{t_{c}} \cdot \overline{S u}\right)^{(16)}$.

Finally, the amounts in reais $(\mathrm{R} \$)$ were converted to the US dollar (US\$), considering a rate of US $\$ 0.26 / \mathrm{R} \$$, based on the exchange rate of January 6,2020 , provided by the Central Bank of Brazil.

\section{Data Analysis and Treatment}

Data were tabulated in electronic spreadsheets by means of independent double typing and, later, treated using descriptive statistics, with calculations of percentages, means, medians, standard deviation (SD), frequencies.

\section{Ethical Aspects}

The research was approved by the Research Ethics Committees of the proposing Institution and of the HPEP through the consolidated opinions no. 3.324.582, on 05/14/2019, and no. 3.373.665, on 06/06/2019, respectively. In full compliance with Resolution No. 466/12, of the National Health Council, data was collected from the medical records of 118 patients treated at the DC (July/2018 and July/2019), ensuring confidentiality and secrecy of the data accessed, and health professionals were invited to participate by signing the Free and Informed Consent Form.

\section{RESULTS}

To support the calculation of the ADC of the seven rescue procedures being studied, 336 non-participating direct observations were performed. Most procedures were performed by a professional in the NA/NT category; the procedure "dressing with topical antibiotic at the insertion site of the CVC" was performed by a nurse and the "insertion of CVC for long-term HD" by three professionals from different categories (a preceptor physician, a resident physician, and a NA/NT).

Table 1 shows the distribution of observations, according to the total ADC of each procedure. Although the procedures "AVF puncture", "topical antibiotic dressing at the CVC insertion site" are the most frequently performed, the "long-term CVC insertions for HD" and "alteplase infusions for CVC unblocking” presented the highest ADCs.

Table 2 shows that in most procedures, ADC with personnel was the most expressive variable, except for "insertion of long-term CVC for HD”, in which ADC with material stood out. Due to the wide variety of drugs used in antibiotic, intravenous, and topical administration procedures, 
Table 1 - Distribution of observations of vascular access rescue procedures, according to type, sample, total ADC, SD, minimum and maximum values - São Paulo-SP, 2020.

\begin{tabular}{lcccc}
\hline Type of vascular access rescue procedures for HD & $\mathbf{n}$ & total ADC US\$ & SD \pm US\$ & Minimum and maximum amounts US\$ \\
\hline Administration of easy-to-dilute antibiotics & 10 & 0.72 & 0.09 & $0.58-0.90$ \\
Administration of difficult-to-dilute antibiotics & 11 & 2.00 & 0.21 & $1.67-2.31$ \\
Administration of undiluted antibiotics & 17 & 1.41 & 0.08 & $1.33-1.49$ \\
Topical antibiotic dressing at the CVC insertion site & 106 & 2.61 & 0.79 & $0.99-4.83$ \\
Alteplase infusion for CVC unblocking & 30 & 48.05 & 0.26 & $47.43-48.39$ \\
Insertion of long-term CVC for HD & 11 & 183.68 & 4.98 & $177.54-195.19$ \\
AVF puncture & 151 & 1.31 & 0.27 & $0.92-2.90$ \\
Total observations & 336 & - & - & - \\
\hline
\end{tabular}

Table 2 - Distribution of ADC with personnel, material, medicines and solutions according to the type of vascular access rescue procedures for HD - São Paulo-SP, 2020.

\begin{tabular}{|c|c|c|c|c|c|}
\hline Type of vascular access rescue procedures for HD & $\begin{array}{l}\text { ADC with } \\
\text { personnel } \\
\text { US\$ }\end{array}$ & $\begin{array}{c}\text { ADC with } \\
\text { material } \\
\text { US\$ }\end{array}$ & $\begin{array}{l}\text { ADC with drugs } \\
\text { US\$ }\end{array}$ & $\begin{array}{l}\text { ADC with } \\
\text { solutions } \\
\text { US\$ }\end{array}$ & $\begin{array}{c}\text { Total ADC } \\
\text { US\$ }\end{array}$ \\
\hline Administration of easy-to-dilute antibiotics & 0.46 & 0.19 & - & 0.07 & 0.72 \\
\hline Administration of difficult-to-dilute antibiotics & 1.28 & 0.37 & - & 0.35 & 2.00 \\
\hline Administration of undiluted antibiotics & 0.72 & 0.37 & - & 0.32 & 1.41 \\
\hline Topical antibiotic dressing at the CVC insertion site & 2.06 & 0.47 & - & 0.08 & 2.61 \\
\hline Alteplase infusion for CVC unblocking & 0.95 & 0.62 & 46.31 & 0.20 & 48.05 \\
\hline Insertion of long-term CVC for HD & 30.17 & 146.07 & 6.35 & 1.09 & 183.68 \\
\hline AVF puncture & 0.69 & 0.54 & 0.00 & 0.08 & 1.31 \\
\hline
\end{tabular}

as well as the cost differences among them, drug costs were not computed.

The costs related to NT/NA DL were more representative in the composition of the ADC of the procedures "administration of easy-to-dilute antibiotics"(63.9\%), "administration of difficult-to-dilute antibiotics" (64\%), "administration of undiluted antibiotics" (51.1\%) and "AVF puncture" (53.0\%); the costs of nurses' DL, in the ADC of the "topical antibiotic dressing at the CVC insertion site" (78.9\%).

In the procedure "alteplase infusion for CVC unblocking", the composition of the total ADC was influenced by the cost of the drug, corresponding to $96.4 \%$ of it. For the $\mathrm{ADC}$ of the procedure "insertion of long-term CVC for HD", the material cost was the main component of total ADC, corresponding to $79.5 \%$ of it.

After obtaining the seven procedures ADC, their costs were estimated from the calculation made from July/2018 to July/2019. In the estimate of ADC of rescue procedures covering the administration of antibiotics, the costs with the drugs were calculated considering the unit cost of each antibiotic multiplied by the amount consumed in the period. For topical antibiotics (used in CVC dressings) the consumption observed in clinical practice (10 grams/procedure) was computed.

Table 3 shows the predominance of the number of procedures "dressing with topical antibiotic at the insertion site of the CVC" (34.2\%), "administration of easy-to-dilute antibiotics" (23.1\%) and "administration of difficult-to-dilute antibiotics" (19.0\%).
Table 3 - Distribution of the number of rescue procedures performed at the DC from July 2018 to July 2019, according to absolute number and percentage - São Paulo-SP, 2020.

\begin{tabular}{lcc}
\hline $\begin{array}{l}\text { Type of vascular access rescue procedures } \\
\text { for HD }\end{array}$ & Amount & $\%$ \\
\hline Administration of easy-to-dilute antibiotics & 285 & $23.1 \%$ \\
$\begin{array}{l}\text { Administration of difficult-to-dilute } \\
\text { antibiotics }\end{array}$ & 235 & $19.0 \%$ \\
Administration of undiluted antibiotics & 94 & $7.6 \%$ \\
$\begin{array}{l}\text { Topical antibiotic dressing at the CVC } \\
\text { insertion site }\end{array}$ & 421 & $34.2 \%$ \\
Alteplase infusion for CVC unblocking & 149 & $12.1 \%$ \\
Insertion of long-term CVC for HD & 6 & $0.5 \%$ \\
AVF puncture & 42 & $3.5 \%$ \\
\hline
\end{tabular}

Finally, the costs of the rescue procedures performed at the DC from July/2018 to July/2019 were estimated. It should be clarified that the costs of the different drugs were added in the estimate of the total ADC of the procedures of antibiotics, intravenous and topical drugs administration presented below.

Among the 285 "easy-to-dilute antibiotic administrations", the costs of the drugs cefazolin and ceftazidime reached US $\$ 418.25$. Adding to this value the total ADC of this procedure (US $\$ 0.72 \times 285=\mathrm{US} \$ 205.20$ ), the total direct cost of US $\$ 623.45$ (100\%) is obtained; $67.1 \%$ related to the cost of medications. 
Table 4 - Distribution of vascular access rescue procedures for HD performed at the DC, from July 2018 to July 2019, according to type, number of procedures and estimate of the total direct cost - São Paulo-SP, 2020.

\begin{tabular}{lcc}
\hline Type of vascular access rescue procedures for HD & Number of procedures performed & Total direct cost US\$- \% \\
\hline Administration of easy-to-dilute antibiotics & 285 & $623.45-5.18 \%$ \\
Administration of difficult-to-dilute antibiotics & 235 & $1,277.42-10.62 \%$ \\
Administration of undiluted antibiotics & 94 & $514.04-4.28 \%$ \\
Topical antibiotic dressing at the CVC insertion site & 421 & $1,290.72-10.74 \%$ \\
Alteplase infusion for CVC unblocking & 149 & $7,159.45-59.55 \%$ \\
Insertion of long-term CVC for HD & 06 & $1,102.08-9.17 \%$ \\
AVF puncture & 42 & $55.02-0.46 \%$ \\
Total & 1232 & $12,022.18-100 \%$ \\
\hline
\end{tabular}

As for the 235 "difficult-to-dilute antibiotic administrations", the costs of the drugs vancomycin and teicoplamine reached US\$807.42. Adding to this value the total $\mathrm{ADC}$ of this procedure (US $\$ 2.00 \times 235=\mathrm{US} \$ 470.00)$, the total direct cost of US $\$ 1,277.42,63.2 \%$ related to the cost of medications.

Regarding the 94 "administrations of undiluted antibiotics", the cost of using the drugs fluconazole, gentamicin, amikacin, ciprofloxacin, and ganciclovir corresponded to US\$381.50. Adding the amount of consumption of antibiotics without the need for dilution, US $\$ 381.50$, to the total ADC of the procedure "administration of undiluted antibiotics" (US $\$ 1.41 \times 94=\mathrm{US} \$ 132.54$ ), we obtain the total direct cost of US\$514.04, 74.2\% corresponding to the cost of drugs.

Regarding the drugs used in the 421 "topical antibiotic dressing at the CVC insertion site" procedures, the total cost of using neomycin, gentamicin, and mupirocin (all in their topical formulation) was US\$191.91. Adding the value of the consumption of topical antibiotics, US\$191.91, to the total $\mathrm{ADC}$ of the procedure "dressing with topical antibiotic at the insertion site of the CVC" (US\$2.61 $\times 421=$ US $\$$ $1,098.81$ ), the total direct cost of US $\$ 1,290.72$ is obtained, $67.2 \%$ of which refer to the cost of the Nurse's DL (US\$ $2.06 \times 421=$ US\$ 867.26).

To estimate the costs of the procedures "alteplase infusion for CVC unblocking", "insertion of long-term CVC for HD" and "AVF puncture" the total ADC of each procedure was multiplied by the amount performed in the DC, obtaining US $\$ 7,159.45$ (149 procedures $\times$ US\$48.05), US $\$ 1,102.08$ (six procedures $\times$ US $\$ 183.68$ ) and US $\$ 55.02$ (42 procedures $\times$ US\$1.31), respectively.

Finally, it can be seen in Table 4 that the estimate of the total direct cost of rescue procedures for vascular access for HD corresponded to US\$12,022.18 (100\%), highlighting the cost of "alteplase infusion for CVC unblocking" (59.55\%), "topical antibiotic dressing at the insertion site of the CVC" (10.74\%) and "administration of difficult-todilute antibiotics" (10.62\%).

\section{DISCUSSION}

The creation and maintenance of vascular access, aiming at the efficiency of $\mathrm{HD}$, affect the costs attributed to CKD, contributing significantly to the financial burden of this modality of $\mathrm{RRT}^{(7)}$. A retrospective American observational study found, in 2013, that Medicare spent US\$ 2.8 billion in vascular access for $\mathrm{HD}$, representing $12 \%$ of the total expenditure on $\mathrm{RRT}^{(17)}$.

Despite the importance of vascular access and the economic impact related to its complications, cost studies on this subject are scarce, especially with regard to the procedures performed to manage vascular access complications.

In the present study, ADCs of seven $\mathrm{HD}$ vascular access rescue procedures were measured, noting that in the procedure "alteplase infusion for CVC unblocking", the composition of the total ADC was significantly influenced by the cost of the medication. In the procedure "insertion of long-term CVC for HD", the cost with material (US\$146.07) was the main component of total ADC. In the other five rescue procedures, the cost with DL of NT/ $\mathrm{NA}$ and nurses was the most expressive component in the composition of total $\mathrm{ADC}$. It is emphasized that knowledge of the costs involved in the provision of health services is essential to support decision-making aimed at the rational and effective allocation of available resources, thus contributing to the cost management and financial sustainability of institutions. Based on the foregoing, $\mathrm{ADC}$ of the procedures mentioned above was affected by the DL of the professionals involved in the rescue procedures performance, due to the time spent and the consumption of inputs (materials, medicines, and solutions).

Studies addressing the cost of such rescue procedures were not found in the literature; however, there was an increase in the production of studies addressing the ADC of procedures performed by nursing professionals and that adopted the same method used in this study ${ }^{(16,18-24)}$.

In view of the financial pressures healthcare organizations have been experiencing, knowledge of the procedures $\mathrm{ADC}$ is essential for managing the cost of each variable that composes it. In this respect, it was found that the cost management of vascular access rescue procedures was favorably influenced due to the rational allocation of the health professionals DL, with the predominance of NT/NA in the participation/performance of procedures, since the NT/NA $\mathrm{DL} /$ minute has a lower value than the nurse $\mathrm{DL} /$ minute. Moreover, this predominance of the NT/NA category was 
considered pertinent because they are professionals who were properly trained and because they mostly had significant experience in the field.

Input (materials, medicines, and solutions) costs have prevailed in the composition of the total ADC of procedures $^{(18-24)}$ and, consequently, the price of their acquisition can have a significant impact on cost management. In the light of this, it was possible to observe that the purchase of inputs by the HPEP, field of this study, is made possible and increased through a bidding process, complying with the principles of legality, impersonality, morality, publicity, and efficiency through an Auction, which aims to provide products at the lowest price in compliance with public notices and contracts aimed at the public interest ${ }^{(25)}$. In addition, at $H P E P$, inputs are purchased in large volumes, which implies greater bargaining power with suppliers and, consequently, increasing the possibility of reducing their purchase price.

The importance of the cost of inputs was evidenced in this study when the total ADC of vascular access rescue procedures for HD was estimated, carried out at the DC between July/2018 and July/2019, totaling US\$12,022.18. The procedure "alteplase infusion for CVC unblocking" had the highest cost, totaling US\$7,159.45 (59.55\%), and had the drug as its main component ( $96.4 \%$ of the total ADC). For the procedure "insertion of long-term CVC for HD", the cost of material represented the most impacting component in the composition of the total $\mathrm{ADC}$, representing $79.5 \%$.

The impact of inputs was also oberved when the cost of antibiotics was included in the composition of the total $\mathrm{ADC}$ of the procedures corresponding to their administration. When drugs were counted, they became the main element in the composition of the ADC of the procedures "administration of easy-to-dilute antibiotics" $(67.1 \%$ of the total ADC), "administration of difficult-to-dilute antibiotics" (63.2\% of total ADC), "administration of undiluted antibiotics" (74.2\%). Only the "topical antibiotic dressing at the insertion site" procedure kept the cost of the nurse's DL as the main component of the total $\mathrm{ADC}$, after the inclusion of topical antibiotics.

The significance of the cost of materials and medicines is demonstrated in other studies on the cost of nursing procedures ${ }^{(18-24)}$ and in the Report of the Institute of Supplementary Health Studies, which, when evaluating a sample of more than one million beneficiaries of health plans, in the period from 2008 to 2012, indicated that materials and medicines were among the items with the greatest variation in cost, corresponding to $60.4 \%$ and $59.2 \%$, respectively ${ }^{(26)}$.

The growth of expenses with health supplies refers to the importance of the qualified participation of nurses in the different stages of the material management process, as management activities linked to care practice favor the accumulation of technical and practical knowledge about materials for nurses, allowing them to consider the selection of materials that best meet the needs of patients/clients who are under their responsibility and care ${ }^{(27)}$, aspects that are essential to cost management of health institutions.

In a context of increased expenses associated with the growing demand for health needs and limited resources ${ }^{(24)}$, cost management is gaining increasing importance as wellmanaged resources, even if scarce, can be used with greater effectiveness and efficiency, subsidizing the financial viability of institutions without harming the quality of care provided.

As a limitation of the present study, there is the option of not taking costs of antibiotics into account when measuring ADC of the observed sample, due to the variety of drugs used in antibiotic administration procedures and the cost differences among them.

As for the implications of this study for clinical practice and research, it represents an advance in generating knowledge about the rescue procedures ADCs for the management of complications of vascular access for HD, a topic on which there is no available literature. The results obtained may direct other DCs to pay for the rescue procedures they perform, adopting the methodology described here, to analyze and reduce, or minimize them, without compromising the quality of care provided.

\section{CONCLUSION}

Among the seven rescue procedures paid for, "alteplase infusion for CVC unblocking" had the composition of total ADC highly determined by the cost of the drug (US\$46.31); "insertion of long-term HD CVC", by the material cost (US\$146.07), and "administration of easy-to-dilute antibiotics", "administration of difficult-to-dilute antibiotics", "administration of undiluted antibiotics", "dressing with topical antibiotic at the CVC insertion site", and "AVF puncture" by the cost of DL (US\$0.46, US\$1.28, US\$0.72, US $\$ 2.06$, US $\$ 0.69$, respectively).

The estimate of the total annual direct cost for 1232 procedures corresponded to US\$12,022.18 (100\%), highlighting the financial representation of the 149 "alteplase infusions for CVC unblocking" (59.55\%), 421 "dressings with topical antibiotic at the CVC insertion site" (10.74\%), 235 "administrations of difficult-to-dilute antibiotics"(10.62\%), and six "long-term CVC insertions for HD" (9.17\%). When drugs were computed in the cost estimate of the procedures "administration of easy-to-dilute antibiotics", "administration of difficult-to-dilute antibiotics", "administration of undiluted antibiotics" corresponded to the main variable in the composition of the total ADC.

\section{RESUMO}

Objetivo: Mensurar o custo direto médio dos procedimentos realizados por profissionais de saúde, em um Centro de Diálise, para o manejo das complicações do acesso vascular para hemodiálise. Método: Pesquisa quantitativa, exploratório-descritiva, do tipo estudo de caso. $\mathrm{O}$ custo direto médio foi calculado multiplicando-se o tempo despendido por profissionais de saúde pelo custo unitário da mão de obra direta, somando-se aos custos de insumos (materiais/medicamentos/soluções). Resultados: Obtiveram-se os seguintes custos diretos médios: US\$0.72, US\$2.00 e US\$1.41 para “administração de antibióticos de fácil, difícil diluição e sem diluição", 
respectivamente; US\$2.61 para “curativo do cateter venoso central com antibiótico tópico"; US\$48.05 para “infusão de alteplase"; US\$183.68 para "inserção de cateter venoso central para hemodiálise”; e US\$1.31 para "punção de Fístula arteriovenosa”. Conclusão: Custos com materiais e medicamentos contribuíram expressivamente para a composição do custo direto médio total da maioria dos procedimentos.

\section{DESCRITORES}

Insuficiência Renal Crônica, Unidades Hospitalares de Hemodiálise, Enfermagem em Nefrologia, Cateterismo Venoso Central, Fístula arteriovenosa, Custos e Análise de Custo.

\section{RESUMEN}

Objetivo: Mensurar el costo promedio directo de los procedimientos realizados por profesionales de salud, en una Unidad de Diálisis, para el manejo de las complicaciones del acceso vascular para hemodiálisis. Método: Investigación cualitativa, exploratorio-descriptiva, del tipo estudio de caso. El costo promedio directo se estimó multiplicándose el tiempo invertido por profesionales de salud por el costo unitario de la mano de obra directa, sumándose a los costos de insumos (materiales/ fármacos/soluciones). Resultados: Fueron encontrados los siguientes costos promedios directos: US\$0.72, US \$2.00 y US\$1.41 para “administración de antibióticos de fácil, difícil dilución y sin dilución”, respectivamente; US\$2.61 para “apósito del catéter venoso central con antibiótico tópico”; US\$48.05 para “infusión de alteplasa”; US\$183.68 para “inserción de catéter venoso central para hemodiálisis"; y US\$1.31 para "punción de Fístula arteriovenosa". Conclusión: Costos con materiales y fármacos contribuyeron expresivamente para la composición del costo promedio directo total de la mayoría de los procedimientos.

\section{DESCRIPTORES}

Insuficiencia Renal Crónica; Unidades de Hemodiálisis en Hospital; Enfermería en Nefrología; Cateterismo Venoso Central; Fístula Arteriovenosa; Costos y Análisis de Costo.

\section{REFERENCES}

1. Kim SH, Jo MW, Go DS, Ryu DR, Park J. Economic burden of chronic kidney disease in Korea using national sample cohort. J Nephrol [Internet]. 2017;30(6):787-93. DOI: http://dx.doi.org/10.1007/s40620-017-0380-3.

2. Li PKT, Ma TKW. Global impact of nephropathies. Nephrology [Internet]. 2017;22(4):9-13. DOI: http://dx.doi.org/10.1111/nep.13146.

3. Ski CF, Thompson DR, Castle DJ. Trialling of an optimal health programme (OHP) across chronic disease. Trials [Internet]. 2016;17(1):445. DOI: http://dx.doi.org/10.1186/s13063-016-1560-5.

4. Teerawattananon Y, Luz A, Pilasant S, Tangsathitkulchai S, Chootipongchaivat S, Tritasavit N, et al. How to meet the demand for good quality renal dialysis as part of universal health coverage in resource-limited settings? Heal Res policy Syst [Internet]. 2016;14:21. DOI: http://dx.doi.org/10.1186/s12961-016-0090-7.

5. Couser WG, Remuzzi G, Mendis S, Tonelli M. The contribution of chronic kidney disease to the global burden of major noncommunicable diseases. Kidney Int [Internet]. 2011;80(12):1258-70. DOI: http://dx.doi.org/10.1038/ki.2011.368.

6. Klarenbach SW, Tonelli M, Chui B, Manns BJ. Economic evaluation of dialysis therapies. Nat Rev Nephrol [Internet]. 2014;10(11):644-52. DOI: http://dx.doi.org/10.1038/nrneph.2014.145.

7. Feldman ZM, Liu LB, Abramowitz SD, Faries PL, Marin ML, Schanzer HR, et al. Hemodialysis vascular access: rising costs as a surrogate marker for patency and function of arteriovenous fistulas. Ann Vasc Surg [Internet]. 2017;38:136-43. DOI: https://doi.org/10.1016/ j.avsg.2016.08.003.

8. Nath KA. Dialysis vascular access intervention and the search for biomarkers. J Am Soc Nephrol [Internet]. 2016;27(4):970-2. DOI: https:// doi.org/10.1681/ASN.2015090982.

9. Neves Junior MA, Petnys A, Melo RC, Rabboni E. Acesso vascular para hemodiálise: o que há de novo? J Vas Bras [Internet]. 2013;12(3):221-5 DOI: http://dx.doi.org/10.1590/jvb.2013.044.

10. Nicole AG, Tronchin DMR. Indicadores para avaliação do acesso vascular de usuários em hemodiálise. Rev Esc Enferm USP [Internet]. 2011;45(1):206-20. DOI: https://doi.org/10.1590/S0080-62342011000100029.

11. Nikolic B. Hemodialysis fistula interventions: diagnostic and treatment challenges and technical considerations. Tech Vasc Interv Radiol [Internet]. 2008;11(3):167-74. DOI: https://doi.org/10.1053/j.tvir.2008.09.003.

12. Feldman ZM, Liu LB, Abramowitz SD, Faries PL, Marin ML, Schanzer HR, et al. Hemodialysis vascular access: rising costs as a surrogate marker for patency and function of arteriovenous fistulas. Ann Vasc Surg [Internet]. 2017;38:136-43. DOI: http://dx.doi.org/10.1016/ j.avsg.2016.08.003.

13. Yin RK. Estudo de caso: planejamento e métodos. 5th ed. Porto Alegre: Bookman; 2015.

14. Martins E. Contabilidade de custos. 11th ed. São Paulo: Atlas; 2018.

15. Castilho V, Lima AFC, Fugulin FMT. Gerenciamento de Custos nos Serviços de Enfermagem. In: Kurcgant P. Gerenciamento em Enfermagem. Rio de Janeiro: Guanabara Koogan; 2016. p. 171-83.

16. Lima AFC, Lima AFC. Direct cost of monitoring conventional hemodialysis conducted by nursing professionals. Rev Bras Enferm [Internet]. 2017;70(2):357-63. DOI: http://dx.doi.org/10.1590/0034-7167-2016-0447.

17. Thamer M, Lee TC, Wasse H, Glickman MH, Qian J, Gottlieb D, et al. Medicare costs associated with arteriovenous fistulas among US hemodialysis patients. Am J Kidney Dis [Internet]. 2018;72(1):10-8. DOI: http://dx.doi.org/10.1053/j.ajkd.2018.01.034.

18. Lima AFC, Castilho V, Baptista CMC, Rogenski NMB, Rogenski KE. Custo direto dos curativos de úlceras por pressão em pacientes hospitalizados. Rev Bras Enferm [Internet]. 2016;69(2):290-7. DOI: http://dx.doi.org/10.1590/0034-7167.2016690212i.

19. Melo TO, Lima AFC. Cost of nursing most frequent procedures performed on severely burned patients. Rev Bras Enferm [Internet]. 2017;70(3):481-8. DOI: https://doi.org/10.1590/0034-7167-2015-0034. 
20. Bel Homo RF, Lima AFC. Direct cost of maintenance of totally implanted central venous catheter patency. Rev Latino-Am Enfermagem [Internet]. 2018;26:e3004. DOI: https://doi.org/10.1590/1518-8345.2263.3004.

21. Lima AFC. Direct costs of integrated procedures of conventional hemodialysis performed by nursing professionals. Rev Latino-Am Enfermagem [Internet]. 2018;26:e2944. DOI: http://dx.doi.org/10.1590/1518-8345.1812.2944.

22. Pires ABM, Lima AFC. Direct cost of peripheral catheterization by nurses. Rev Bras Enferm [Internet]. 2019;72(1):88-94. DOI: https://doi. org/10.1590/0034-7167-2018-0250.

23. Furlan MS, Lima AFC. Direct cost of procedures for phlebitis treatment in an Inpatient Unit. Rev Esc Enferm USP [Internet]. $2020 ; 54: e 03647$. DOI: https://doi.org/10.1590/S1980-220X2019011403647.

24. Sportello EF, Castilho V, Lima AFC. Coverage for the cost of outpatient nursing procedures by the Unified Health System: a percentage analysis. Rev Esc Enferm USP [Internet]. 2021;55:e03692. DOI: https://doi.org/10.1590/S1980-220X2019026803692.

25. Brasil. Lei N 8.666, de 21 de junho de 1993. Regulamenta o art.37, inciso XXI, da Constituição Federal, institui normas para licitações e contratos da Administração Pública e dá outras providências [Internet]. Brasília; 1993 [cited 2020 Mar 6]. Available from: http://www. planalto.gov.br/ccivil_03/leis/l8666cons.htm.

26. Leite F. Porque os custos com internação dos planos de saúde são os que mais crescem? [Internet]. Instituto de Estudos de Saúde Suplementar: São Paulo; 2013 [cited 2020 Feb 1]. Available from: http://www.iess.org.br/html/TDIESS0048pqcustoscrescem.pdf.

27. Bogo PC, Bernardino E, Castilho V, Cruz EDA. The nurse in the management of materials in teaching hospitals. Rev Esc Enferm USP [Internet]. 2015;49(4):629-35. DOI: http://dx.doi.org/10.1590/S0080-623420150000400014. 